\title{
OZONE PHOTOCHEMICAL POLLUTION OVER THE NORTH OF ALGERIA: CARTOGRAPHY AND MODELLING
}

\author{
NASSIMA OUCHER ${ }^{1,2,3}$, RABAH KERBACHI ${ }^{2}$, GIORGIO PASSERINI $^{3}$, \\ STEFANO CARLETTI ${ }^{3}$ \& NOUREDDINE YASSAA ${ }^{1}$ \\ ${ }^{1}$ Centre de Développement des Energies Renouvelables (CDER), Algeria \\ ${ }^{2}$ Laboratoire des Sciences et Techniques de l'Environnement, Ecole Nationale Polytechnique (ENP), Algeria \\ ${ }^{3}$ Università Politecnica delle Marche, Italy
}

\begin{abstract}
Tropospheric ozone cartography was established for the first time over the north of Algeria in this work. A set of 50 passive sampling tubes were distributed over Algiers city. The cartography was carried out by the ArcGIS software. The results shows that the highest $\mathrm{O}_{3}$ levels were mainly recorded in the east part of Algiers and to a lesser degree, in the west part. In addition, the ozone data of the Algiers Air Quality Monitoring Network was used to test the RAMS-EPS3-CAMx model system for ozone over the north of Algeria. It shows that there is relatively good agreement between the measured and predicted data with a clear diurnal ozone distribution. The ozone spatial evolution obtained from observation and modelling was relatively similar albeit some registered deviations.
\end{abstract}

Keywords: ozone, road traffic, cartography, ArcGIS, modelling, RAMS-EPS3-CAMx, Algiers.

\section{INTRODUCTION}

Monitoring of photochemical pollution by ozone $\left(\mathrm{O}_{3}\right)$ and its precursors, $\mathrm{NO}_{\mathrm{x}}$ and volatile organic compounds (VOCs), in rural, suburban and urban areas, has become a major concern for scientists and local authorities, owing to their harmful impact on the human health, environment, agriculture products and ecosystems [1]. While in the developed countries, this form of pollution is well documented, this is unfortunately not the case in North Africa and Algeria in particular where all the necessary conditions for the formation of this pollution are met.

In recent years, several studies on air pollution caused by ground-level ozone in cities around the world have shown its influence on the degradation of air quality [2]-[9], greenhouse potential and contribution to climate radiative forcing [10]. Therefore, ozone is one of the six criteria pollutants regulated by the US Environmental Protection Agency (EPA) through National Ambient Air Quality Standards (NAAQS) [11]. WHO's health protection threshold of $\mathrm{O}_{3}$ is estimated at $160 \mu \mathrm{g} / \mathrm{m}^{3}$ in one hour [12].

Several studies have highlighted that the main emission source of pollutants in big cities is road traffic. The changes in the volume and speed of vehicles (traffic activity), vary over time and across urban areas and can affect vehicle emissions of air pollutants [13]. Thus, some authors estimated that about $70 \%$ of $\mathrm{NO}_{\mathrm{x}}$ emitted into the atmosphere in large cities are attributable to road traffic [14] and that ground-level ozone and its precursor $\mathrm{NO}_{\mathrm{x}}$ concentrations come from transport emissions [15]. Ozone is a significant air quality problem in the São Paulo Metropolitan Area (SPMA) in Brazil. In the atmosphere of the SPMA, the main sources of ozone precursors are emissions from gasoline-ethanol-, and diesel-powered vehicles [16]. With hydrocarbons, the $\mathrm{NO}_{\mathrm{x}}$ are the main precursors of photochemical ozone [17]-[20]. The major contributions of $\mathrm{NO}_{\mathrm{x}}$ and $\mathrm{CO}$ are from mobile sources, mainly from vehicular sources on road networks in urbanised area [21]. Ozone formation is a well-known phenomenon resulting from complex chemical reactions of nitrogen oxides and organic 
species in the presence of favorable meteorological conditions and in particular solar radiation [9], [22].

Among the biggest cities of the Mediterranean basin, the metropolitan area of Algiers (latitude north $36^{\circ} 43^{\prime}$ ) houses an important road traffic, with total length of the road network about 2,346 km [23]. It is characterized by a moderate Mediterranean climate of low thermal amplitude with a little jelly. Both climatic constraints are the winds dominant west that require windbreaks and the hail that occurs on average 12 days/year in the Sahel. The annual average temperature varies between 16 and $18^{\circ} \mathrm{C}$. The rainfall are on average of $735 \mathrm{~mm} /$ year with exceeding of $100 \mathrm{~mm} /$ year of this mean for the months of November, December and January [23]. Algeria enjoys strong sunshine; the annual average sunshine varies between 2,600 hours/year in the north to 3,500 hours/year in the Highlands and the south [24]. These latter, meet all the conditions that can cause intense oxidizing pollution [19].

Owing to the strong growth of urban traffic road, in recent years, Algiers totals now quarter of the entire national vehicle park. In ten years (between 2002 and 2013), the fleet of the agglomeration of Algiers grew by roughly $50 \%$ to about 1,326,667 vehicles in 2013 . Passenger cars account for $70 \%$ of the total, followed by light-duty vehicles with $21 \%$ and finally the trucks with 3\% [25]. Algiers' population was estimated to 2,701,224 inhabitants in 2002 and 3,090,986 inhabitants in 2013 [26]. The socio-economic development that the country has experienced in recent years and the improving quality of life of the population, have induced a strong growth of the fleet which was estimated in 2013 to 5,123,705 vehicles in Algeria [26]. This situation creates certainly a degradation of air quality by increasing air pollution emissions. For all these reasons, the aim of this work is to evaluate the levels of ozone in Algiers City Area. The passive sampling technique Radiello tubes were employed for the first time in Algeria, to map up the ozone air pollution in urban areas. Two measurement campaigns were performed on 50 sites in Greater Algiers and enabled the determination of ozone ambient air levels. Their spatiotemporal distributions were established using a spatial probabilistic interpolation method, available in the Geostatistical Analyst extension of ArcGIS (version 10). On the other hand, as the spatial modelling is a key tool of air pollution management, we have tested the RAMS-EPS3-CAMx model system for $\mathrm{O}_{3}$ in the large city of Algiers. A network of air monitoring stations, emission inventories and dispersion models were useful tools and were used together. In addition, the evolution of ozone levels established from these two techniques were compared.

\section{METHOD AND MODEL DESCRIPTION}

The dispersion phenomenon of tropospheric ozone pollution in Algiers city illustrated by cartography is explored by the application of a particular form of kriging, namely ordinary kriging. The obtained cartography also allows better vision on the most polluted areas. The kriging procedure is dependent on the local spatial structure of the photochemical process of ozone formation and should be able to adapt to trends in the data. The aims are therefore:

- to cartography the mean $\mathrm{O}_{3}$ in Algiers city; and

- to evaluate the use of ordinary kriging by the cartography of standard deviation of the mean $\mathrm{O}_{3}$.

In addition, the Comprehensive Air Quality Model with Extensions (CAMx) photochemical grid model (ENVIRON, 2010) for the Algerian domain is applied using the emissions, meteorology and boundary conditions (BCs) provided by the AQMEII and furthermore investigated the influence of input data, assumptions and uncertainties on CAMx model performance. In the following sections, we discuss the application of CAMx to north Algeria using the input data provided by "National Inventory of Greenhouse Gas Emissions", 
model sensitivity analyses including use of alternate input data/assumptions, and $\mathrm{O}_{3}$ sensitivity to precursor emissions (anthropogenic $\mathrm{NO}_{\mathrm{x}}$ and VOC).

\subsection{Cartography methodology}

Cartography is the most suitable means for good spatial representation. Geostatistics is an approach that characterizes the structure of the spatial variability of any property, and its estimation turns out to be very appropriate to map a natural phenomenon [27].

Kriging is an interpolation technique that has been developed since the 1950s by the South African geologist Krige, but it was only in the 1960s that Matheron and Mining School Team of Paris have formulated the theory of regionalized variables, hence the name of Geostatistics [27].

ArcGIS is a geographic information system developed by ESRI (Environmental Systems Research Institute). It is a tool to manage, view, map, query, and analyse all the data with a spatial component. ArcGIS includes increasing functionality ArcView, ArcEditor, and ArcInfo. Interpolation methods are numerous and complex, with an efficiency, highly variable. The selection of one or the other is logically conditioned by the expected representativeness of the desired results and fixed objectives. The geostatistics term refers to the study of natural phenomena [27]. It has two phases [28]:

1. The first is the spatial analysis of the study variable through the variogram (variography): The characterization of structures of the spatial variability or structural analysis is the first step necessary for any geostatistical study.

2. The second is the use of a technique of spatial prediction using as tool the kriging. Kriging is a prediction technique taking into account the information provided by the variogram, which is also a probabilistic spatial interpolation method. It is probabilistic as far as it considers the spatial field of the variable as a realization of a random function.

Cartography is the final outcome of geostatistics. Thus, after estimating the value of a property at any point of a domain, obtaining a map is easy.

Two sampling campaigns during the summer seasons (8-19 July 2012 and 23 June to 4 July 2013) were performed in an area covering 49 sampling sites, distributed over all communes of Algiers city (Fig. 1). The majority of sampling sites are either a semi urban or rural type.

In contrast to the dynamic sampling, the passive sampling method allows covering a large number of measurement sites over large areas at a reasonable cost. Using the Radiello Passive Sampler, the cartridge for the adsorption of $\mathrm{O}_{3}$ represents a microporous polyethylene tube filled with silica gel coated with 4,4'-dipyridylethylene [29]. The $\mathrm{O}_{3}$ trapped by adsorption, is desorbed with 3-methyl-2-benzothiazolinone hydrazone (MTBH) and analysed by photometry. In outdoor environments, the Radiello Passive Sampler can be fixed at a position from 2 to $3 \mathrm{~m}$ in height.

Based on the obtained results and employing the technique of geostatistics "ArcGIS" (by variography and ordinary kriging), the cartography of air pollution by tropospheric ozone in Algiers City was developed.

\subsubsection{Modelling methodology}

The modelling system "RAMS-EPS3-CAMx" used in this study consists of:

- RAMS: Mesoscalemeteological model: a coastal region is influenced by many meteorological phenomena due to the interactions between breezes and large-scale wind systems; 


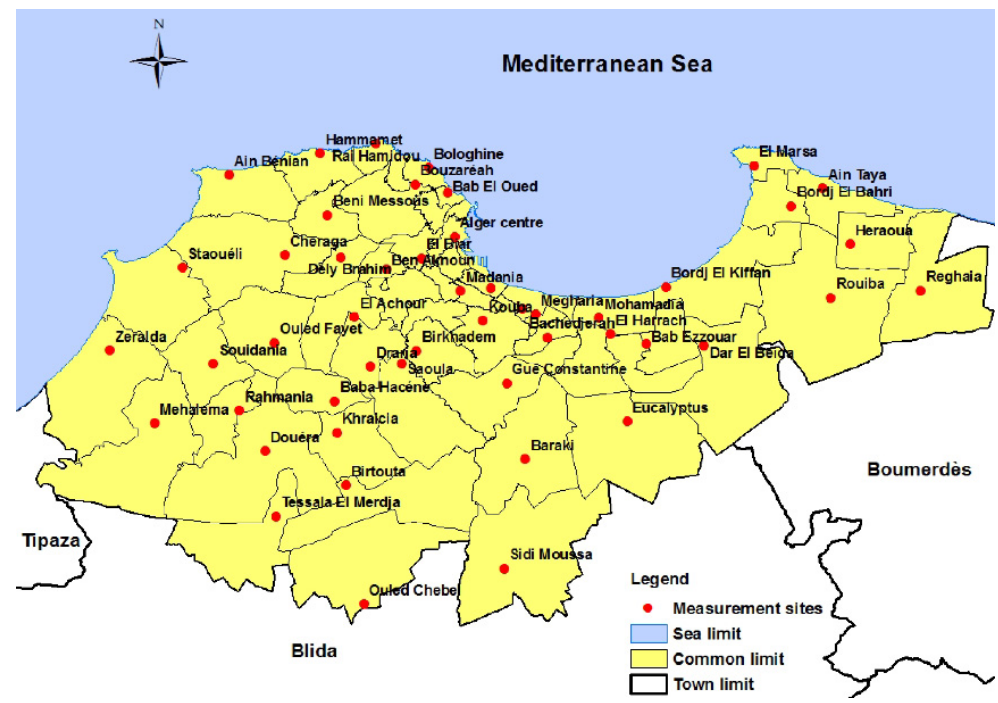

Figure 1: Location of measurement sites.

- EPS3: (emissions progressing system, version 3.20) is a modelling system that generates hourly gridded speciated emission for photochemical grid models: air emission inventories;

- CAMx: (comprehensive air quality model with extensions) is an Eulerian photochemical dispersion model: CAMx simulates the emission, dispersion, chemical reaction, and removal of pollutants in the troposphere.

The data requirements of CAMx are:

- Meteorology: Supplied by a meteorological model: using in our case RAMS to have the hourly meteorological data for the selected period which give the 3-dimensional gridded fields;

- Air quality: Obtained from measured ambient data: using EMEP values which give the gridded initial concentrations and gridded boundary concentrations;

- Emissions: Supplied by an emissions model: using national inventory of greenhouse gas emissions for the year 2000 for EPS3, that give the elevated point sources and combined gridded sources;

- Geographic: Developed from terrain and landuse/landcover maps, drought index maps, modelled or satellite derived snow cover, satellite-derived leaf area index (LAI): using orography and land use received by National Institute of Cartography and Telecommunication (INCT) and treated by ArcGIS that give the gridded surface characteristics;

- Photolysis: Derived from satellite measurements and radiative transfer models: using satellite data from NOAA for the selected periods and areas that give the atmospheric radiative properties.

The model requires concentrations measured continuously by monitoring station. For this purpose, we have taken into consideration the data provided by the network monitoring air quality "SAMASAFIA" where one of the four measuring stations, "Ben Aknoun" station is 
equipped with an ozone analyser (Fig. 2). For this station, the data used are from 2002 (2124 June). The choice of the year is due, firstly, to the fact that this station has encountered many problems and has worked well with consistent results only in 2002. On the other hand, emissions used in the model are taken from the National Inventory of Greenhouse Gas Emissions for the year 2000 [30] as the only source of emissions inventory available to this date on Algeria. It is assumed that emissions from inventory 2000 are quite close to those of 2002. The meteorological data required for modelling, are those recorded at the Dar El Bieda station that is representative of Greater Algiers (see Fig. 2).

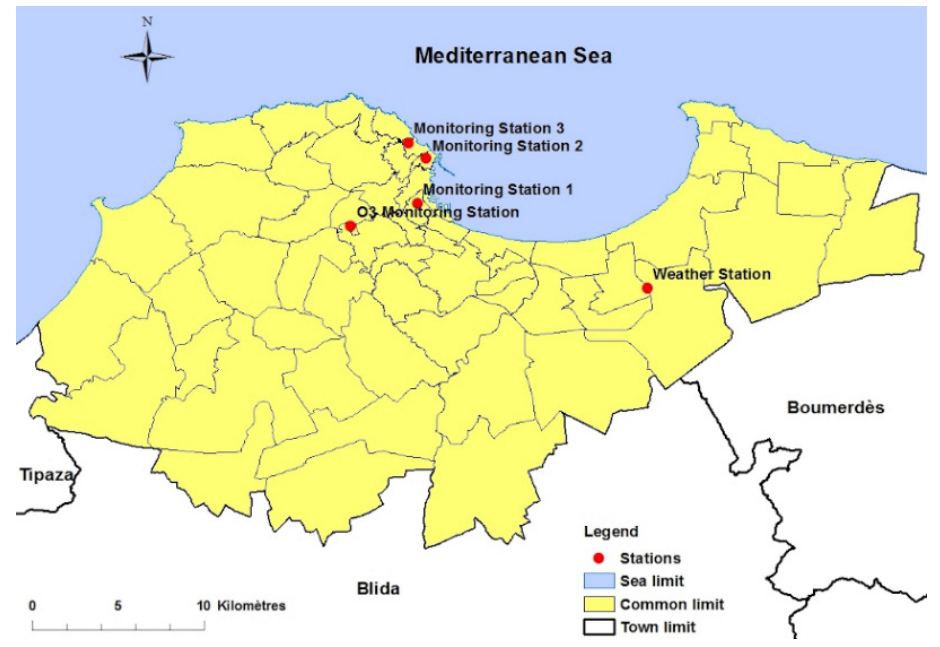

Figure 2: Location of measurement stations.

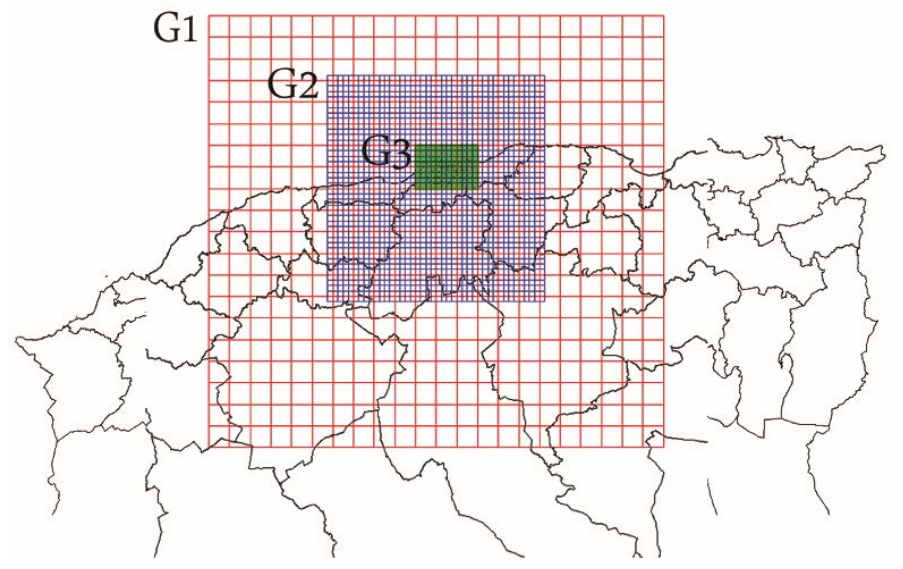

Figure 3: Master grid G1 and nested grids.

The model evaluation was performed using the EPS3 (Emissions Processing System, version 3.20) tool for the gas pollutants $\mathrm{O}_{3}, \mathrm{NO}_{2}, \mathrm{NO}$, and COV and included a spatial and a temporal analysis. The Ben Aknoun monitoring station (Fig. 2) was considered for the air 
quality results of the spatial model RAMS-CAMx. Besides that, the whole of north Algeria domain was split into three subdomains G1, G2 and G3 as shown in Fig. 3.

The coarse grid (G1), as shown in Fig. 3, is $440 \times 400 \mathrm{~km}$ wide and covers most northern Algeria region through its 22 x 20 cells with $20 \mathrm{~km}$ step. The second nested grid (G2) is 200 x $200 \mathrm{~km}$ wide, covers Algiers and neighboring towns well, and is made of $40 \mathrm{x} 40$ cells of $5 \mathrm{~km}$ steps. The finest grid (G3) is $60 \times 40 \mathrm{~km}$ wide and is made of $62 \times 42$ cells of $1 \mathrm{~km}$ steps. It covers Algiers city (our study area).

\section{RESULTS AND DISCUSSION}

\subsection{Cartography results}

The results of the cartography of the summer mean $\mathrm{O}_{3}$ are given in Fig. 4. The mean levels of pollution vary from 142.67 to $204.53 \mu \mathrm{g} / \mathrm{m}^{3}$. The lowest values are measured in and around the center of Algiers. Compared to other Mediterranean cities like Athens where $\mathrm{O}_{3}$ varies from 64 to $80 \mu \mathrm{g} / \mathrm{m}^{3}$ [31], Madrid with an $\mathrm{O}_{3}$ mean level of $38.5 \pm 3.5 \mu \mathrm{g} / \mathrm{m}^{3}$ [30] and Volos with an $\mathrm{O}_{3}$ maximum value of $69 \pm 17 \mu \mathrm{g} / \mathrm{m}^{3}$, Algiers presents a high photochemical pollution. The cartography shows that it is mainly the east part of Algiers and to a lesser extend the west part where we recorded the highest ozone levels. Globally, the levels increase progressively from the center of Algiers going to the east and west of the town.

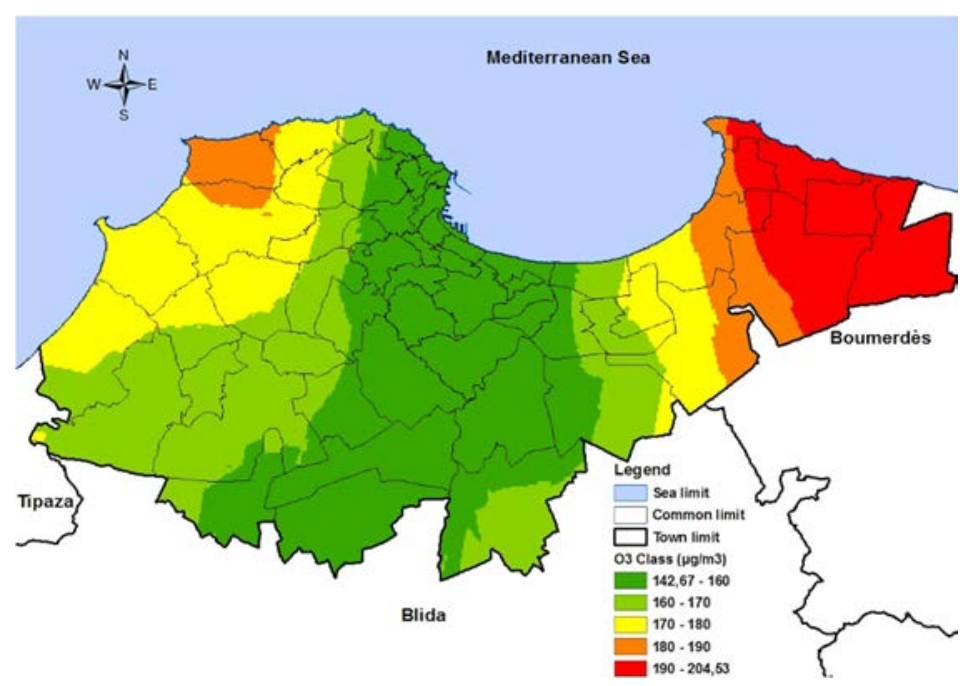

Figure 4: Cartography of mean ozone over the two summers.

The distribution of values expressed by the standard deviation given in Fig. 5 shows that the levels are relatively homogeneous in central Algiers $\left(22.30\right.$ to $\left.24 \mu \mathrm{g} / \mathrm{m}^{3}\right)$ and spread slightly more in the east and west extremities $\left(27.57 \mu \mathrm{g} / \mathrm{m}^{3}\right)$.

As already mentioned in the introduction, the ozone is governed by the transport of its precursor pollutants (VOC and $\mathrm{NO}_{\mathrm{x}}$ ). The examination of meteorological data shows that in the agglomeration of Algiers, the prevailing winds in summer are usually (NE, ENE, N, W, and NW) [33], These considerations explain the high levels of ozone measured in the east and west of Algiers in low-polluted areas. 


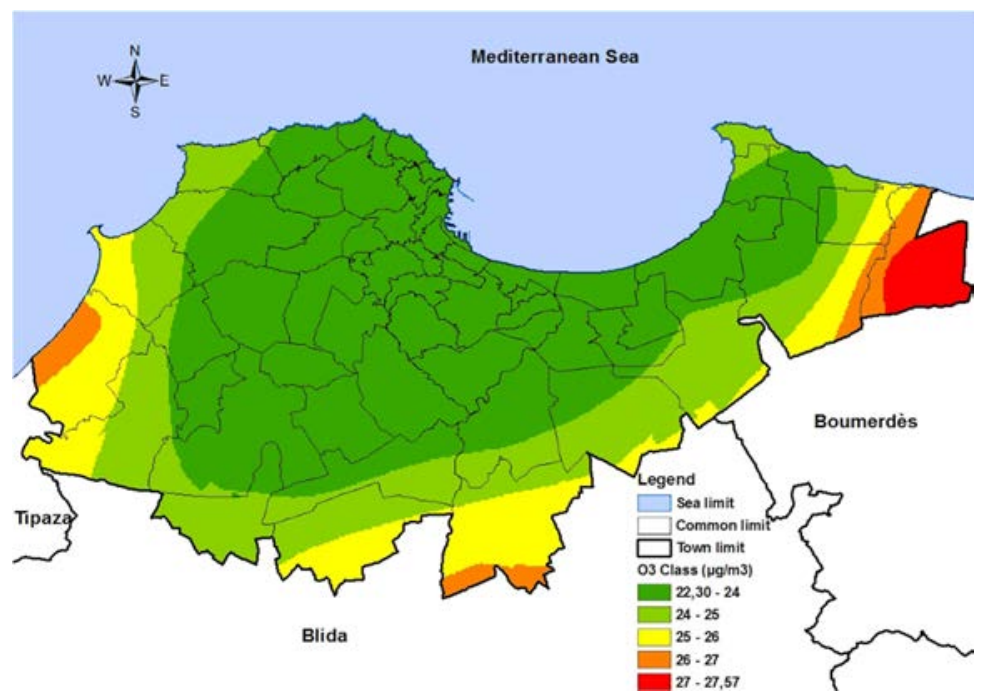

Figure 5: Cartography of standard deviation of ozone mean.

Previous studies have shown that the center of Algiers is the subject of intense pollution from road traffic [34], [35]. Indeed, the Algerian vehicle fleet estimated at 5,123,705 vehicles at the end of 2013 with 1,326,657 vehicles in Algiers, which represents $25.89 \%$ of the national vehicle fleet. At Algiers, the car ownership rates is 330 vehicles/1,000 inhabitants, which is more than the double of the national average [26].

For example in Algiers, the levels of $\mathrm{NO}_{\mathrm{x}}$ have reached levels of the order of $68 \mu \mathrm{g} / \mathrm{m}^{3}$ [36], Moreover, total PAH in downtown of Algiers ranged from $5.510^{-3}$ to $43.410^{-3} \mu \mathrm{g} / \mathrm{m}^{3}$ [37]. The PAHs mean cumulative concentrations have reached $6.46210^{-3} \mu \mathrm{g} / \mathrm{m}^{3}$ at RouibaRéghaia, industrial district of Algiers [38]. BTEX which are also an indicator of vehicle pollution often reach higher levels of around $229.46 \mu \mathrm{g} / \mathrm{m}^{3}$ for total BTEX in Algiers [39]. The magnitude of these ozone precursors' pollutants is undoubtedly at the origin of the formation of ozone near the city center in areas where vehicle emissions are lower.

As suggested by some authors [31], [40], the transport of these pollutants by prevailing winds drove under the influence of solar radiation at photochemical ozone production [41].

\subsection{Modelling results}

The modelling system RAMS-EPS3-CAMx simulates well the behavior of ozone in Algiers city. The diurnal variations of $\mathrm{O}_{3}$ concentrations during the modelling period of four days (21-24 June 2002) are shown in Fig. 6. The results show that, the ozone concentrations during these four days follow a characteristic diurnal course for polluted region with high concentrations during mid or afternoon (indicating obviously higher photochemical pollution induced by road traffic) and low concentrations during late night or early morning (ozone destruction takes place) and a big variation in magnitude between daytime and night-time.

Fig. 7 illustrates the typical ozone diurnal variation (23 June 2002), this day presented a minimum value at 1:00 am and 10:00 pm, i.e., the ozone minimum before sunrise caused by destruction of ozone at soil and eventually by early rush-hour traffic. The daily peak value appeared around 12:00. 


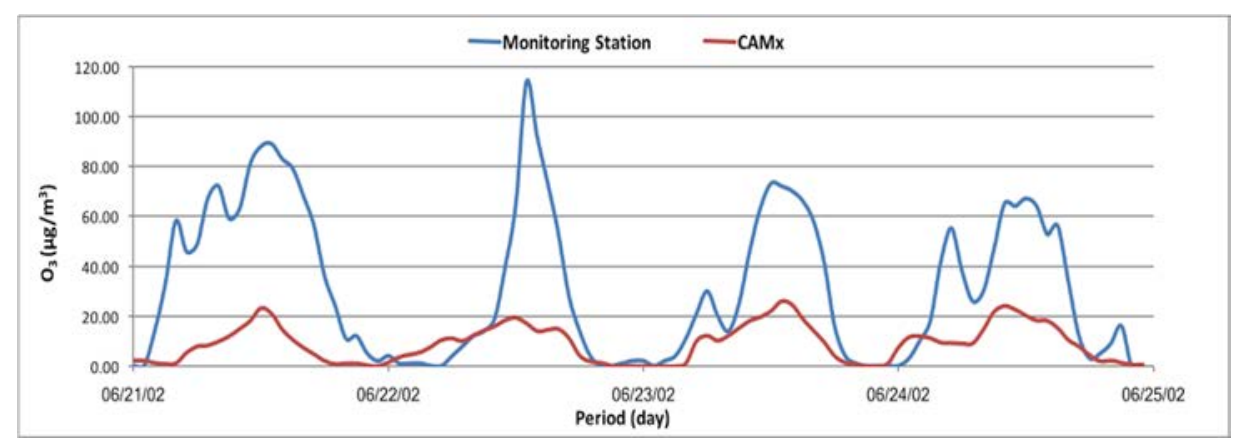

Figure 6: Diurnal variations of ozone concentrations.

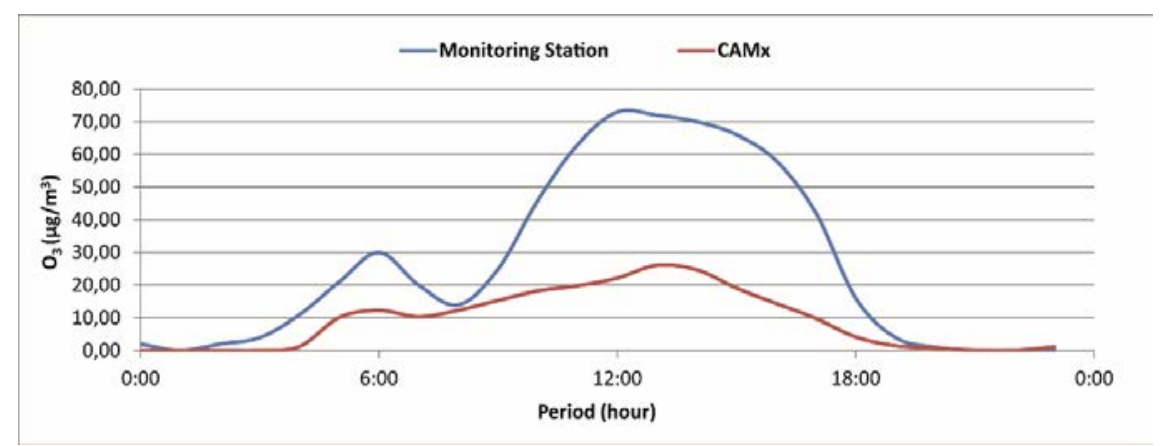

Figure 7: Ozone typical diurnal variation.

The predicted concentrations are more or less in agreement with measurements of the monitoring station. The differences are larger in the first days of simulation, and then become smaller. Due to the self-tuning, the model needs at least two days of simulation to give acceptable results. Using the official inventory in simulations, the resulted ozone values are much lower than those observed; a similar values have been reported by a previous study [16].

The emission inventories are often the largest source of uncertainty in model predictions such as the RAMS-EPS3-CAMx model. Because ozone precursor sensitivity depends critically on emission rates for anthropogenic $\mathrm{VOC}$ and $\mathrm{NO}_{\mathrm{x}}$. Moreover, control strategies establish that ozone concentrations are difficult to predict if there are no reliable data on emissions and concentrations of ozone precursors as is the case of Algeria. Knowing that, the National Inventory of Greenhouse Gas Emissions for the year 2000 contains several approximations and assumptions due to the lack of data on emissions, particularly in fugitive emissions. This explains the differences between the measured data and the predicted data. The model reproduces the global trend of daily diurnal ozone.

\subsection{Comparison cartography and modelling results}

The approach used was to normalize relatively to the average ozone values measured for the two summer campaigns in all sites and represented by the mean Fig. 8. Similarly, a 
normalization relative to the average of the results of modelling "RAMS-EPS3-CAMx" apportioned across all measurement sites has allowed the calculation of the contribution rate in ozone pollution of the entire measurement sites represented by CAMx 2002 (Fig. 8).

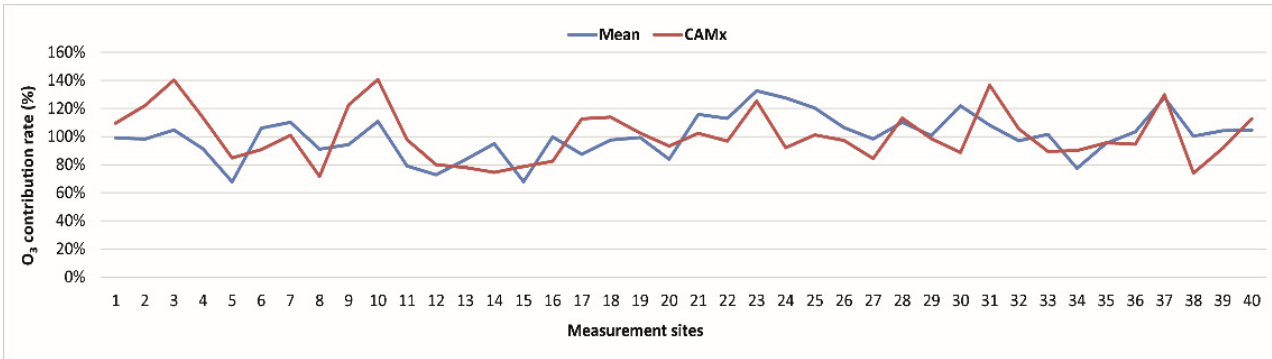

Figure 8: Evolution of ozone contribution rate.

Therefore, a comparison of the evolution of the pollution contribution rate by ozone of the set of measurement sites in our study (Fig. 8) for both passive and active techniques have been possible. This comparison shows an agreement in the evolution of the pollution contribution for both techniques with the exception of some existing differences particularly at the sites 3,14,16, 30, 33 and 38 corresponding respectively to municipalities (Zeralda, Kouba, Saoula, Bad Ezzouar, Megharia and Ben Aknoun) (see Fig. 1) characterized as urban sites where we had seen (Fig. 5) that the standard deviation relative to the ozone pollution was relatively large in this type of site.

\section{CONCLUSIONS}

An investigation of a descriptive cartography of passive measurements as well as modelling of active measurements of air pollution by tropospheric ozone of the great Algiers has been achieved, for the first time. Ozone levels varied from 142.67 to $204.53 \mu \mathrm{g} / \mathrm{m}^{3}$. The spatial distribution of ozone shows that the levels increase progressively from the center of Algiers going to the east and west of Algiers. The ozone levels determined in the present work were higher than those measured in Greece $\left(120 \mu \mathrm{g} / \mathrm{m}^{3}\right)$ [31], in Toulon in France $\left(114 \mu \mathrm{g} / \mathrm{m}^{3}\right)$, in Roma in Italy $\left(115 \mu \mathrm{g} / \mathrm{m}^{3}\right)$ [42]. However, they were in the same range than those recorded in Genova in Italy $\left(142 \mu \mathrm{g} / \mathrm{m}^{3}\right)$, in Toledo in Spain $\left(129 \mu \mathrm{g} / \mathrm{m}^{3}\right)$ and lower than those measured in Malaga (Spain) (160 and $\left.190 \mu \mathrm{g} / \mathrm{m}^{3}\right)$ [43]. For the suburban sites, the average measured concentrations were higher than those recorded at the center in Pécs in Hungary $\left(127 \mu \mathrm{g} / \mathrm{m}^{3}\right)$ [31], in Athina in Spain $\left(129 \mu \mathrm{g} / \mathrm{m}^{3}\right)$, in Milano in Italy $\left(126 \mu \mathrm{g} / \mathrm{m}^{3}\right)$ and lower than those recorded at the center of Zagreb in Croatia $\left(209 \mu \mathrm{g} / \mathrm{m}^{3}\right)$ [44].

The modelling system RAMS-EPS3-CAMx indicates that tropospheric ozone concentrations follow a characteristic diurnal distribution with high concentrations in the early afternoon hours when radiation and temperature favour ozone formation and low concentrations during the late night hours. The diurnal profiles showed a characteristic pattern in most city centres, with minimum values in the early morning hours, a strong rise during the morning, peak concentrations in the afternoon, and a decline during the night. The widest amplitudes between minimum and maximum values were found in central and southern European cities such as Dusseldorf, Verona, Klagenfurt, Lyon or Barcelona. In the northern European cities of Edinburgh and Copenhagen, by contrast, maximum values were lower and diurnal variation was much smaller. 
This study shows that greater Algiers is subject to photochemical air pollution whose precursors arise from road traffic, which is in continuous growth. It is very likely that the photochemical air pollution in Algiers will be even more exacerbated with climate warming.

Only the Spanish cities did not fit this pattern; there, ozone levels were again lower than in central European cities, probably due to the direct influence of strong car traffic emissions. In general, ozone concentrations and cumulative exposure were significantly higher at suburban sites than at urban and traffic-exposed sites.

The highest levels of ozone are generally recorded in suburb areas where the influence of road traffic is lower [45]. The application of the RAMS-EPS3-CAMx model shows that there is relatively good agreement between the measured and predicted data. The discrepancy is due to the lack of data in the emission inventory of ozone precursors. The results of the model depend directly on the quality and accuracy of the emissions. In addition, the comparison gives an overall agreement in the evolution of the pollution contribution rate by ozone for the set of measurement sites employing both techniques (passive and active).

The tested model can be used for the prediction studies and allows to simulate a good approximation of future evolutions of tropospheric ozone in the context of future climate change. Due to similar climate and socioeconomic development, the obtained results in this work can be considered as representative of the southern Mediterranean countries.

\section{ACKNOWLEDGEMENT}

This work was carried out within the scholarship of a PNE "Exceptional National Program" grant from our Ministry of Higher Education and Scientific Research (MERS).

\section{REFERENCES}

[1] Caballero, S., Galindo, N., Pastor, C., Varea, M. \& Crespo, J., Estimated tropospheric ozone levels on the southeast Spanish Mediterranean coast. Atmospheric Environment, 41, pp. 2881-2886, 2007.

[2] Beck, J.P., Reeves, C.E., de Leeuw, F.A.A.M. \& Penkett, S.A., The effect of aircraft emissions on tropospheric ozone in the northern hemisphere. Atmospheric Environment, 26, pp. 17-29, 1992.

[3] Chan, L.Y., Liu, H.Y., Lam, K.S., Wang, T., Oltmans, S.J. \& Harris, J.M., Analysis of the seasonal behavior of tropospheric ozone at Hong Kong. Atmospheric Environment, 32(2), pp. 159-168, 1998.

[4] Guicherit, R. \& Roemer, M., Tropospheric ozone trends. Chemosphere, 2, pp. 167$183,2000$.

[5] Hsu, K.-J., Relationships between ten-year trends of tropospheric ozone and temperature over Taiwan. Science of the Total Environment, 374, pp. 135-142, 2007.

[6] Krzyscin, J., Krizanb, P. \& Jaros'awskia, J., Long-term changes in the tropospheric column ozone from the ozone soundings over Europe. Atmospheric Environment, 41, pp. 606-616, 2007.

[7] Kulkarni, P.S., Bortoli, D., Salgado, R., Antón, M., Costa, M.J. \& Silva, A.M., Tropospheric ozone variability over the Iberian Peninsula. Atmospheric Environment, 45, pp. 174-182, 2011.

[8] Oltmans, S.J., Lefohn, A.S., Harris, J.M., Galbally, I., Scheel, H.E., Bodeker, G., Brunke, E., Claude, H., Tarasick, D., Johnson, B.J., Simmonds, P., Shadwick, D., Anlaufi, K., Haydeni, K., Schmidlin, F., Fujimoto, T., Akagi, K., Proias, G.T., Larissi, I., Kmoustris, K.P, Nastos, P.T. \& Paliatsos, A.G., Assessment of surface ozone variability in an urban coastal area at the eastern Mediterranean. Global NEST Journal, 15, pp. 163-168, 2013. 
[9] Bilge, O., Gulsen, A.K., Senay, Ç.D. \& Savas, A., Predicting tropospheric ozone concentrations in different temporal scales by using multilayer perceptron models. Ecological Informatics, 6, pp. 242-247, 2011.

[10] IPCC, Climate change: The physical science basis, contribution of Working Group I to the Fourth Assessment Report (AR4) of the Intergovernmental Panel on Climate Change, p. 996, 2007.

[11] Li, T., Horton, R.M., Bader, D.A., Huang, G., Sun, Q. \& Kinney, P.L., Heat-related mortality projections for cardiovascular and respiratory disease under the changing climate in Beijing, China. Scientific Reports, 5, 11441, 2015.

[12] WHO (World Health Organisation), www.who.org. Accessed on: 5 Jun. 2015.

[13] Batterman, S., Temporal and spatial variation in allocating annual traffic activity across an urban region and implications for air quality assessments, Transportation Research Part D, 41, pp. 401-415, 2015.

[14] Joumard, R., Quels polluants? Contribution des transports. Pollution Atmosphérique, 121, pp. 5-8, 1989.

[15] Oliver, G.H., Day of week effects on diurnal ozone/ $\mathrm{NO}_{\mathrm{x}}$ cycles and transportation emissions in Southern California. Transportation Research Part D, 12, pp. 292-305, 2007.

[16] Andrade, M. de F., Ynoue, R.Y., Harley, A.R. \& Miguel, H., Air quality model simulating photochemical formation of pollutants: The São Paulo Metropolitan Area, Brazil. International Journal of Environment and Pollution, 22, pp. 460-475, 2004.

[17] Butler, J.O., Air Pollution Chemistry, Academic Press: London, 408 pp., 1979.

[18] Toupance, G., L'ozone dans la basse troposphère: Théorie et pratique. Pollution Atmosphérique, 177, pp. 32-42, 1988.

[19] Kerbachi, R., Boughedaoui, M., Koutai, N. \& Lakki, T., La pollution par les oxydes d'azotes et l'ozone à Alger. (The nitrogenoxides and ozone pollution in Algiers.) Pollution Atmosphérique, pp. 89-101, 1998.

[20] Kerbachi, R., Boughedaoui, M. \& Koutai, N., Etude de l'ozone troposphérique et de ces précurseurs, les oxydes d'azotes, à Alger. 2ème Conférence Maghrébine sur le Génie des Procédés (COMAGEP2), Djerba, Tunisia, 1996.

[21] Vongmahadlek, C., Zhang, M., Satayopas, B. \& Pham, T.B.T., Using a photochemical air quality model to evaluate emissions and simulate concentrations. International Journal of Environment and Pollution, 45, pp. 342-352, 2011.

[22] Elkamel, A., Abdul-Wahab, U.S., Bouhamra, W. \& Alper, E., Measurement and prediction of ozone levels around a heavily industrialized area: A neural network approach. Advances in Environmental Research, 5, pp. 47-59, 2001.

[23] ONS (National Office of Statistics), Statistical Yearbook of the Algiers Town, Algeria. www.ons.dz. Accessed on: 10 Apr. 2011.

[24] Yaiche, M.R. \& Bouhanik, A., Atlas Solaire Algerien, Centre de Développement des Energies Renouvelables, 2013.

[25] Berrah, M.K., Parc national automobile au 31/12/2011, ISSN 1111-5939, 618, 2011.

[26] ONS (National Office of Statistics), Algeria. www.ons.dz. Accessed on: 30 Mar. 2013.

[27] Droesbeke, J.J., Lejeune, M. \& Saporta, G., Analyse statistique des données spatiales. Editions TECHNIP, Paris, France, 2006.

[28] Douaoui, A., Variabilité spatiale de la salinité en relation avec certaines caractéristiques des sols de la plaine du Bas-Chéliff. Apport de la géostatistique et de la télédétection. Doctoral thesis, INA-Alger, 230 pp., 2005.

[29] Fondazione Salvatoremaugeri-IRCCS, Manuel Radiello, Centre de Recherches Environnementales, PADOVA, Italy. www.radiello.com. Accessed on: 1 Mar. 2012. 
[30] MATET, Inventaire national des émissions de gaz à effet de serre de l'année 2000. Projet 00039149/GEF/PNUD, 2010.

[31] Kalabokas, P.D., Viras, L.G., Bartzis, J.G. \& Repapis, C.C., Mediterranean rural ozone characteristics around the urban area of Athens. Atmospheric Environment, 34, pp. 5190-5208, 2000.

[32] Martin, P., Chabans, B., Villanueva, F., Gallego, M.P., Colmenar, I. \& Salgado, S., Ozone and nitrogen dioxide levels monitored in urban area (Ciudad Real) in centralsouthern Spain. Water Air and Soil Pollution, 208, pp. 305-316, 2010.

[33] ONM (National Office of Meteorology), Frequency distribution of the wind on 16 directions and 4 speed classes (in \%), period 1990-2010, Algiers. www.meteo.dz. Accessed on: 20 May 2013.

[34] Yassaa, N., Meklati, B.Y., Brancaleoni, E., Frattoni, M. \& Ciccioli, P., Polar and nonpolar volatile organic compounds (VOCs) in urban Algiers and Saharian sites of Algeria. Atmospheric Environment, 35, pp. 787-801, 2001.

[35] Boughdaoui, M., Chikhi, S., Berrouane, N., Bacha, I. \& Kerbachi, R., Caractérisation du parc automobile et pollution de l'air à Alger. Colloque International Environnement et Transports dans des Contextes Différents, Ghardaïa, Algeria, 2009.

[36] SAMASAFIA, Billan Annuel 2009, Réseau de Surveillance de La Qualité de l'Air d'Alger (SAMASAFIA), Algiers, Algeria, 2009.

[37] Yassaa, N., Meklati, B.Y., Cecinato, A. \& Marino, F., Particulate n-alkanes, n-alkanoic acids and polycyclic aromatic hydrocarbons in the atmosphere of Algiers City area. Atmospheric Environment, 35, pp. 1843-1851, 2001.

[38] Yassaa, N., Ladji, R., Balducci, C., Cecinato, A. \& Meklati, B.Y., Distribution of the solvent-extractable organic compounds in fine (PM1) and coarse (PM1-10) particles in urban, industrial and forest atmospheres of Northern Algeria. Science of the Total Environment, 408, pp. 415-424, 2009.

[39] Kerchich, Y. \& Kerbachi, R., Measurement of BTEX (benzene, toluene, ethybenzene, and xylene) levels at urban and semirural areas of Algiers City using passive air samplers. Journal of the Air and Waste Management Association, 62, pp. 1370-1379, 2012.

[40] Jallad, K.N. \& Espada-Jallad, C., Analysis of ambient ozone and precursor monitoring data in a densely populated residential area of Kuwait. Journal of Saudi Chemical Society, 14, pp. 363-372, 2010.

[41] Carletti, S. \& Passerini, G., Tropospheric ozone behavior as a function of precursor emissions. Doctoral School on Engineering Sciences, Università Politecnica delle Marche, Energy Sciences, 2014.

[42] AEE (European Environment Agency), Air pollutant concentrations at station level (statistics), Data Prod-ID: DAT-150-en. www.eea.europa.eu/data-and-maps/data/airpollutant-concentrations-at-station. Accessed on: 26 Apr. 2018.

[43] Duenas, C., Fernandez, M.C., Canete, S., Carretero, J. \& Liger, E., Analyses of ozone in urban and rural sites in Malaga (Spain). Chemosphere, 56, pp. 631-639, 2004.

[44] Pehnec, G., Vađić, V., Bešlić, I. \& Žužul, S., Summer ozone concentrations in Zagreb area. ArhHig Rada Toksikol, 60, pp. 35-42, 2009.

[45] Pilar, M., Beatriz, C., Florentina, V., Maria Paz, G., Inmaculada, C. \& Sagrario, S., Ozone and nitrogen dioxide levels monitored in an urban area (Ciudad Real) in centralsouthern Spain. Water Air and Soil Pollution, 208, pp. 305-316, 2010. 